\title{
Transformation of Diesel range Hydrocarbons by inorganic Double Salts
}

\author{
${ }^{* 1}$ ACHUGASIM, O; ${ }^{1}$ UMOFIA, E. \\ ${ }^{I}$ Department of Pure and Industrial Chemistry, \\ University of Port Harcourt, Rivers State Nigeria \\ *Corresponding author email:ozioma.achugasim@uniport.edu.ng
}

\begin{abstract}
Ability of double salts: Ammonium cobalt (1l) sulphate hexahydrate $\left(\mathrm{NH}_{4}\right)_{2} \mathrm{Co}$ $\left(\mathrm{SO}_{4}\right)_{2} \cdot 6 \mathrm{H}_{2} \mathrm{O}$ and Potassium aluminium sulphate dodecahydrate $\mathrm{KAl}\left(\mathrm{SO}_{4}\right)_{2} \cdot 12 \mathrm{H}_{2} \mathrm{O}$ to degrade diesel range hydrocabons (DRH) were investigated by treating a sample of diesel with the double salts at elevated temperature of $200^{\circ} \mathrm{C}$. The degradation or otherwise of the hydrocarbons in the treated and untreated diesel samples were determined using Gas chromatography (GC). The results showed that the double salts were able to alter the hydrocarbon fingerprint of the diesel sample as the $\mathrm{C}_{11}-\mathrm{C}_{14}$ aliphatic hydrocarbons were drastically reduced and the $\mathrm{C}_{16}-\mathrm{C}_{36}$ range of hydrocarbons experienced noticeable increase. The hump for unresolved complex mixtures was retained in all the chromatograms, showing that the salts were unable to alter the oxygenated compounds in the diesel sample. () JASEM
\end{abstract}

http://dx.doi.org/10.4314/jasem.v21i1.20

Keywords: Diesel, double salt, Hydrocarbons, Gas Chromatography

The largest source of hydrocarbons found in nature is crude oil. Its hydrocarbon content can reach as high as $90 \%$ depending on the type of crude oil. The hydrocarbons found in crude oil are many and varied. They could be aliphatic or aromatic. The aromatic hydrocarbon could be simple or complex. The simple ones have one benzene ring in their structure while the complex ones have two or more benzene rings in their structures. Others have aromatic heterocyclic rings in them. The aliphatic hydrocarbons found in crude oil are of many compound types: They are the straight chain, branched and the cyclic hydrocarbons more popularly known as the paraffins, isoparaffins and the naphthenes respectively (Achugasim et al., 2013 and Osuji et al., 2006). These hydrocarbons vary in chain length and ring size depending on the formation from which the crude oil is obtained.

During petroleum/crude oil refining, the hydrocarbons are separated according to their size/chain length and the consequent boiling points into useful products or fractions.

These products include liquefied petroleum gas (LPG), gas oil, premium motor spirit (PMS), kerosene, diesel, lubricating oil etc. each of these products is made up of a range of hydrocarbons instead of a specific one (Okoye, 2009, Osuji, 2011 and Ojinnaka, 2012). The hydrocarbon types found in the diesel fraction are called diesel range organics (DRO) or diesel range hydrocarbons (DRH). The diesel range organics are made up of both aliphatic and aromatic hydrocarbons. The diesel range aliphatics (DRA) are long (straight or branched) usually longer than the ones found in either kerosene or Premium Motor Spirit (P.M.S). They contain 12 to 25 carbon atoms and boil between $250^{\circ} \mathrm{C}-400^{\circ} \mathrm{C}$. Consequently cracking of the DRA could convert them into aliphatic hydrocarbons found in PMS or kerosene which boils at lower temperature ranges. Stories abound of locales in the Niger Delta Nigeria, who boil diesel fuel which is readily available with salts to convert them to a fuel that can be used by petrol engines during perennial PMS scarcity that usually plague Nigeria. The aromatic content of the diesel range organics are primarily the polycyclic aromatic hydrocarbons (PAH). They as well can be transformed or broken down into the simple or one ring aromatics (Hyne, 2001; Leahy and Colwell, 1990). These break down of large or long hydrocarbons into smaller or simpler ones can be achieved using different methods. One of the methods is high temperature (thermal cracking) another is the use of catalysts at moderate temperatures (catalytic cracking). A number of catalysts have been used and they include zeolites, inorganic salts etc (Wellinton and Asmus, 1995; Okoye 2009 and Jimoh 2004).

Double salts have demonstrated strong ability in catalysis. A double salt is an inorganic salt that contains two different cations and anions. They are produced by the combination of two or more different salts that are crystallized in the same ionic 
lattice. They usually form large crystals more readily than the single salts. Their properties are not the same with the properties of its component single salts. They dissolve or dissociate in water to give the simple ions unlike the complex salts that dissociate to give complex ion that remain intact in solution (Ayhan, 2008). Examples of double salts includes: Ammonium cobalt (1l) sulphate hexahydrate $\left(\mathrm{NH}_{4}\right)_{2} \mathrm{Co}\left(\mathrm{SO}_{4}\right)_{2} \cdot 6 \mathrm{H}_{2} \mathrm{O}$, Potassium aluminium sulphate dodecahydrate $\mathrm{KAl}\left(\mathrm{SO}_{4}\right)_{2} \cdot 12 \mathrm{H}_{2} \mathrm{O}$, ammonium nickel sulphate hexahydrate $\left(\mathrm{NH}_{4}\right)_{2} \mathrm{Ni}\left(\mathrm{SO}_{4}\right)_{2} \cdot 6 \mathrm{H}_{2} \mathrm{O}$ etc. The present research will study the use of gas chromatography (GC) to monitor the degradation or transformation of Diesel range aliphatics (DGA) in samples of diesel fuel treated with two double salts: ammonium cobalt (11) sulphate hexahydrate $\left(\mathrm{NH}_{4}\right)_{2} \mathrm{Co}\left(\mathrm{SO}_{4}\right)_{2} \cdot 6 \mathrm{H}_{2} \mathrm{O}$, and potassium aluminium sulphate dodecahydrate $\mathrm{KAl}\left(\mathrm{SO}_{4}\right)_{2} \cdot 12 \mathrm{H}_{2} \mathrm{O}$.

\section{MATERIALS AND METHODS}

Five grams of the different double salts in powder form were measured into dry $500 \mathrm{ml}$ conical flasks. Subsequently $200 \mathrm{ml}$ of commercial diesel were introduced into each of the flasks and the mixture was heated up to $200^{\circ} \mathrm{C}$ for eight hours. The content of the flask was cooled down and allowed to stand for 48hours for complete reaction. Another beaker with the same content without the salts was used as control with the process repeated. Samples were taken from the flasks and sent to the laboratory for GC analysis of their aliphatic hydrocarbon content. The GC analysis was done with an Agilent machine with the same condition and procedure as reported in Achugasim et al., (2013) and Osuji and Achugasim (2010).

\section{RESULT AND DISCUSSION}

The result of the total petroleum hydrocarbon analysis of the diesel samples are presented in table 1 and their chromatograms shown in figures 1-3. The chromatogram in figure 3 is depicting the fingerprints of the untreated diesel sample for comparison.

Table 1: The concentrations of aliphatic hydrocarbons in treated and untreated diesel samples

\begin{tabular}{|c|c|c|c|}
\hline HYDROCARBONS & $\begin{array}{c}\text { DIESEL + } \\
\left(\mathrm{NH}_{4}\right)_{2} \mathrm{Co}\left(\mathrm{SO}_{4}\right)_{2} .6 \mathrm{H}_{2} \mathrm{O} \\
(\text { Amt. of hydrocarbon }(\mathrm{ppm}))\end{array}$ & $\begin{array}{l}\text { DIESEL + KAl }\left(\mathrm{SO}_{4}\right)_{2} \cdot \mathbf{1 2 H}_{2} \mathrm{O} \\
(\text { Amt. of hydrocarbon }(\mathrm{ppm}) \text { ) }\end{array}$ & $\begin{array}{c}\text { UNTREATED DIESEL } \\
\text { (Amt. of hydrocarbon(ppm)) }\end{array}$ \\
\hline$\overline{C_{12}}$ & 3.95 & 5.99 & 1.09 \\
\hline $\mathbf{C}_{13}$ & 44.20 & 9.62 & 2.02 \\
\hline $\mathrm{C}_{14}$ & 117.40 & 11.27 & 3.43 \\
\hline $\mathbf{C}_{15}$ & 2495.00 & 136.38 & 134.87 \\
\hline $\mathrm{C}_{16}$ & 1937.39 & 688.695 & 28.05 \\
\hline $\mathrm{C}_{17}$ & 2039.24 & 8150.67 & 452.75 \\
\hline PRISTANE & BDL & 14318.80 & 2472.99 \\
\hline $\mathrm{C}_{18}$ & 23897.20 & 4539.49 & 1476.04 \\
\hline PHYTANE & 42036.70 & 23897.00 & 3409.27 \\
\hline $\mathrm{C}_{19}$ & 4749.09 & 4301.40 & 4101.74 \\
\hline $\mathrm{C}_{20}$ & 10677.01 & 4749.09 & 26153.40 \\
\hline $\mathbf{C}_{21}$ & 234.15 & 101950.00 & 28681.45 \\
\hline $\mathrm{C}_{22}$ & 3030.149 & 1036.52 & 10372.70 \\
\hline $\mathbf{C}_{23}$ & 581.99 & 1149.60 & 6303.67 \\
\hline $\mathrm{C}_{24}$ & 9982.31 & 13048.00 & 7168.28 \\
\hline $\mathrm{C}_{25}$ & 1591.90 & 11484.90 & 8529.71 \\
\hline $\mathrm{C}_{26}$ & 401.61 & 15688.24 & 212.00 \\
\hline $\mathrm{C}_{27}$ & 157.54 & 856.39 & 123.57 \\
\hline $\mathrm{C}_{28}$ & 33.21 & 304.68 & 40.72 \\
\hline $\mathrm{C}_{29}$ & 87.21 & 27.97 & 22.63 \\
\hline $\mathrm{C}_{30}$ & 30.54 & 152.23 & 24.27 \\
\hline $\mathrm{C}_{31}$ & 32.05 & 76.75 & 11.76 \\
\hline $\mathrm{C}_{32}$ & 65.35 & 46.42 & 16.95 \\
\hline $\mathrm{C}_{33}$ & 50.08 & 20.61 & 51.67 \\
\hline $\mathbf{C}_{34}$ & 30.53 & BDL & 32.32 \\
\hline $\mathrm{C}_{35}$ & BDL & BDL & 18.98 \\
\hline $\mathrm{C}_{36}$ & BDL & BDL & 194.56 \\
\hline $\mathbf{C}_{37}$ & BDL & BDL & BDL \\
\hline $\mathrm{C}_{38}$ & $\mathrm{BDL}$ & BDL & BDL \\
\hline
\end{tabular}

BDL $=$ Below Detectable Limit.

The results show that the double salts were able to alter the hydrocarbon fingerprints of the diesel sample used. The particular hydrocarbons altered could not be ascertained as the long chain 
hydrocarbons were still present in the $\mathrm{GC}$ result of the treated sample. However, the $\mathrm{C}_{11}-\mathrm{C}_{14}$ ranges of hydrocarbons from the chromatogram of the treated samples are indicative of conversion of hydrocarbon in the untreated samples. There is no proof that the aforementioned hydrocarbon ranges are the products of disintegration of the longest chain hydrocarbon from the untreated diesel sample. It is worthy of note that some of the hydrocarbons in the $\mathrm{C}_{16}-\mathrm{C}_{36}$ experienced drastic and intriguing increase in their concentration. These may be as a result of the cracking of some of the hydrocarbons in the diesel sample used. The effect of the two different double salts on the hydrocarbons of the diesel sample seems to be the same as the shape of their chromatograms are akin to each other. The unresolved complex mixtures that usually appear as humps in chromatograms were seen in all the samples showing that the double salts were unable to alter the oxygenated compounds in the diesel sample used.

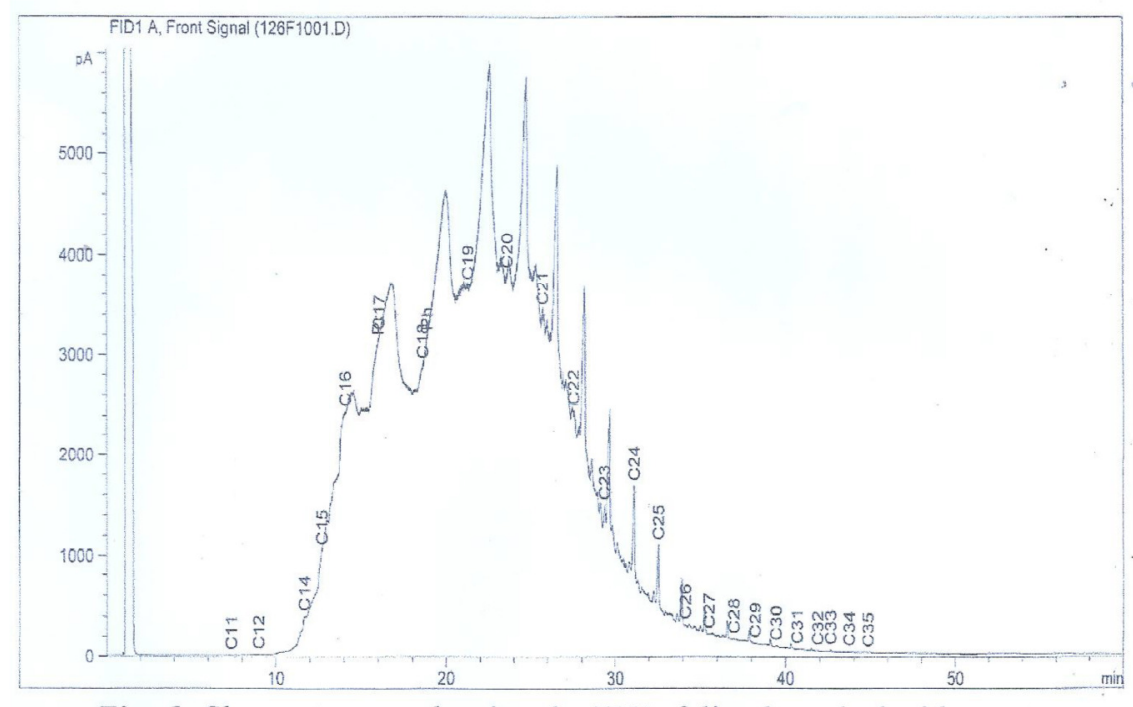

Fig 1: Chromatogram showing the hydrocarbon peaks of the diesel sample after treatment with $\left(\mathrm{NH}_{4}\right)_{2} \mathrm{Co}$ $\left(\mathrm{SO}_{4}\right)_{2} \cdot 6 \mathrm{H}_{2} \mathrm{O}$.

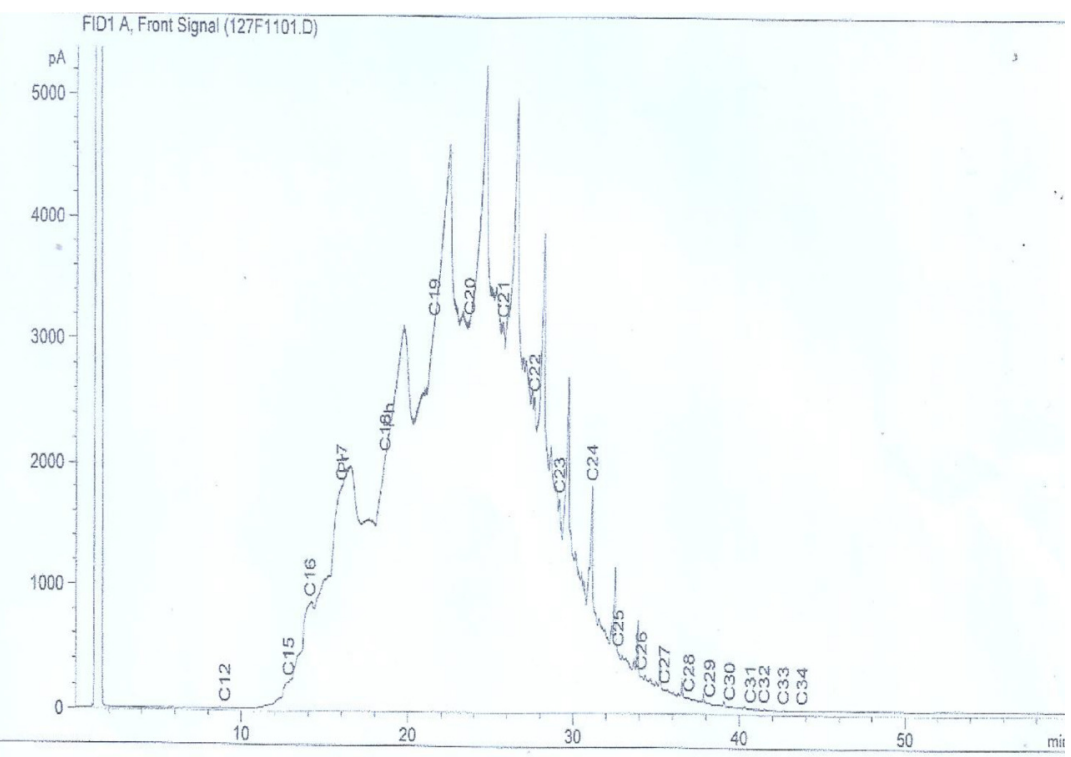

Fig 2: Chromatogram showing the hydrocarbon peaks of the diesel sample after treatment with KAl $\left(\mathrm{SO}_{4}\right)_{2} .12 \mathrm{H}_{2} \mathrm{O}$ 


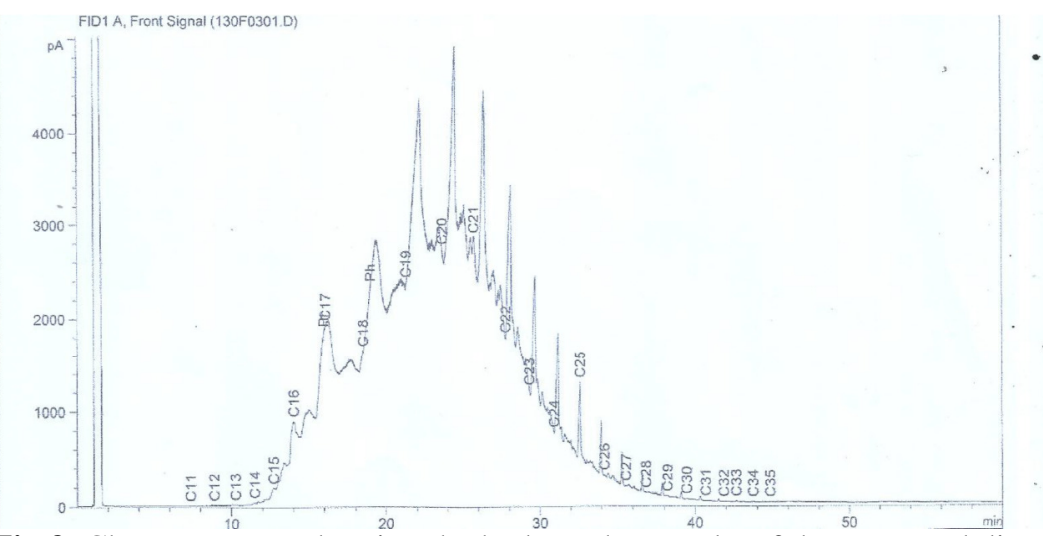

Fig 3: Chromatogram showing the hydrocarbon peaks of the untreated diesel sample.

The study has therefore shown that treatment of diesel with double salts alters their hydrocarbon signature though in an unpredictable manner. It is also pertinent to say that the double salts did not remove the unresolved complex mixtures (UCM) found in the chromatogram of the untreated diesel sample, showing that they lack the ability to reverse oxidation of some of the hydrocarbons in the diesel sample. It is therefore recommended that fingerprinting studies on the double salt - treated diesel samples be carried out to ascertain and possibly predict the exact manner in which the hydrocarbon are degraded(Harris, 1999).

Acknowledgement: The authors are very grateful to Amni International for their assistance in the GC analysis of the diesel samples.

\section{REFERENCES}

Achugasim,O, Ojinnaka,C, Osuji,L(2013)

Management of petroporphyrins in a crude oil polluted environment. Eur. Chem. Bull. 2(10)794-796.

Ayhan, D (2008) Biodiesel : A realistic fuel alternative for diesel engines. Springer,Berlin, p74.

Hyne,N J(2001) Nontechnical guide to petroleum Geology, exploration, drilling and Production. RennWell, Alexandria. pp 1-4.

Harris, D C (1999) Gas chromatography: Quantitative chemical analysis. Freedman and company, London, pp675-712.
Jimoh,A (2004) The use of diesel oil treated with inorganic salts: an alternative to kerosene.

Aust. J. Tehnol. 8(1) 27-37.

Leahy,J.G, Colwell,R R (1990) Microbial degradation of petroleum in the environment. Microb. Rev. 53(3) 305-315.

Ojinnaka,C, Osuji,L, Achugasim, O (2012) Remediation of hydrocarbons in crude oil contaminated soil using fenton's reagent. Environ. Monit. Assess. 184(11)6527-6540.

Ojinnaka,C M (2012) An introduction to principles of organic chemistry. Kemispect Associates, Port Harcourt, pp169-178.

Okoye, I P (2009) fundermentals of petroleum and hydrocarbon chemistry. Allwell Publishers, Port Harcourt. pp30-46.

Osuji,L C, Udoetok,I A, Ogali,R E (2006). Attenuation of Petroleum Hydrocarbons by Weathering: A case study. Chem. Bio. Div. 3: 422-433.

Osuji,L C, Achugasim,O (2010) trace metals and volatile aromatic hydrocarbon content of ukpeliede-I oil spillage site, Niger Delta Nigeria. J.Appl. Sc.Environ. Mgt. 14(2) 17-20.

Osuji, L C (2011) Petroleum Chemistry and Toxicology: In theory and practice. Jeso International, Owerri, pp71-90.

Wellinton, B F, Asmus, A F (1995) Diesel engines and fuel systems. Longman, Sydney, pp56-69. 